\title{
Effect of temperature and salinity on the toxicity of nickel and zinc to two estuarine invertebrates (Corophium volutator, Macoma balthica)
}

\author{
V. Bryant, D. M. Newbery, D. S. McLusky \& R. Campbell \\ Department of Biological Science, The University, Stirling, Scotland FK9 4LA, United Kingdom
}

\begin{abstract}
Acute toxicity of nickel and zinc to 2 estuarine invertebrates (Corophium volutator, Macoma balthica) has been studied at 3 temperatures $\left(5,10,15^{\circ} \mathrm{C}\right)$ and a range of salinities $(5$ to $35 \%$, in $5 \%$ increments), at time intervals up to $384 \mathrm{~h}$. Median survival times with nickel and zinc decreased for both species as salinity decreased. Increases in temperature also caused a decrease in median survival time for $C$. volutator with both metals, and for $M$. balthica with zinc but not with nickel. From analysis of variance, significant factors and their interactions were included in response surface models for C. volutator and $M$. balthica separately for each element. Results indicate that the environmental variables of temperature and salinity should be considered when evaluating toxicity of nickel and zinc in the estuarine environment.
\end{abstract}

\section{INTRODUCTION}

Although there are comprehensive data on the acute toxicity of nickel and zinc to marine invertebrates (e.g. Portmann 1968, Ahsanullah 1976, 1982, Eisler \& Hennekey 1977), there has only been 1 study on the effects of varying temperature and salinity on nickel toxicity to an estuarine species. Denton \& Burden-Jones (1982) measured the influence of temperature and salinity on the acute toxicity of heavy metals, including nickel, to the tropical banana prawn (Penaeus merguiensis). They found that the toxicity of all metals increased at higher temperatures, and that the toxicity of all metals tested, except nickel, increased at lower salinities. For nickel, toxicity was greater at high salinity and high temperature, although the authors stated that the differences were not significant. Babich \& Stotsky (1983) found that nickel toxicity to microbes in marine systems was reduced by increasing the salinity, decreasing temperature and incorporating simulated sediments.

There have been several reports on the effect of temperature and salinity on zinc toxicity. Jones (1975) and Fernandez (1983) both reported that zinc toxicity increased at higher temperature and lower salinity. McKenney \& Neff (1979), in a study on the effects of temperature, salinity and zinc on the larval develop- ment of the grass shrimp Palaemonetes pugio, found viability reduced outside the optimal ranges of 17 to $27 \%$ and 20 to $27^{\circ} \mathrm{C}$ and that survival through complete larval development was progressively reduced in the presence of zinc. Larval resistance to zinc was greatest under optimal conditions, and was reduced at higher and lower temperatures and salinities. The present study was undertaken to establish the effect of temperature and salinity on nickel and zinc toxicity to 2 species of invertebrates which are of ecological importance in European estuaries, the amphipod Corophium volutator Pallas and the bivalve Macoma balthica (L.).

\section{MATERIALS AND METHODS}

Corophium volutator and Macoma balthica were collected from the 'unpolluted' Tay estuary at Tayport, which has a salinity range of 11 to $32 \%$ (Khayrallah \& Jones 1975). Experiments were conducted in a constant temperature room at $5,10,15^{\circ} \mathrm{C}\left( \pm 0.5 \mathrm{C}^{\circ}\right)$, with a regime of $12 \mathrm{~h} \mathrm{light,} 12 \mathrm{~h}$ darkness. The acute toxicity of nickel (as nickel chloride) and zinc (as zinc sulphate) was determined using static tests following standard protocol (Anonymous 1980). Stock solutions of Analar grade $\mathrm{NiCl}_{2} \cdot 6 \mathrm{H}_{2} \mathrm{O}$ and $\mathrm{ZnSO}_{4} \cdot 7 \mathrm{H}_{2} \mathrm{O}$ were 
prepared in water of the appropriate salinity and nominal concentrations of test solution obtained by dilution. At 25 and $35 \%$, some precipitation of zinc was observed in solutions of 1,000 and $2,000 \mathrm{ppm}$. Saline solutions were prepared by dilution of natural seawater with deionized water; $35 \%$ salinity was prepared by the addition of Gerrard's sea salt to natural seawater.

The nickel experiment for Corophium volutator used a $3 \times 7 \times 5$ factorial design, with temperatures of 5,10 and $15^{\circ} \mathrm{C}$, nickel concentrations of $2,4,8,16,32,64$ and $128 \mathrm{ppm}$ (+ controls) and salinities of $5,10,15,25$ and $35 \%$. The nickel experiment for Macoma balthica had a $3 \times 8 \times 3$ factorial design with the same temperature as above, nickel concentrations of $16,32,64,128$, 256, 512, 1,000 and $2,000 \mathrm{ppm}$ (+ controls) and salinities of 15,25 and $35 \%$.

The zinc experiment for Corophium volutator used a $3 \times 8 \times 5$ factorial design, with the same temperatures and salinities as in the nickel experiment, and zinc concentrations of $1,2,4,8,16,32,64$ and $128 \mathrm{ppm}$ ( + controls). The zinc experiment for Macoma balthica had a $3 \times 8 \times 3$ factorial design, with the same temperatures and salinities as the nickel experiment, and zinc concentrations of $15,30,60,125,250,500,1000$ and $2000 \mathrm{ppm}$ (+ controls). M. balthica is unable to survive at salinities of less than $15 \%$ for more than $24 \mathrm{~h}$. Animals were acclimated to each salinity and temperature for $5 \mathrm{~d}$ before testing. Experiments were conducted at the appropriate season $\left(\right.$ e.g. $5^{\circ} \mathrm{C}$ in winter). The oxygen concentration, $\mathrm{pH}$, temperature and salinity and metal concentration in the test vessels were monitored regularly. Over a $24 \mathrm{~h}$ period $\mathrm{pH}$ did not vary by more than 0.5 in any vessel, and dissolved oxygen did not drop below $75 \%$ of air saturation. Nickel and zinc analyses showed that metal concentrations did not fall below $90 \%$ of the initial value over a $24 \mathrm{~h}$ period. Twenty individuals of each species were used for each combination of levels of temperature, salinity and metal. Sterile sand was provided as substrate in all test vessels and no food was provided throughout the experiment. Vessels were examined, dead animals removed and test solutions changed daily for $384 \mathrm{~h}$.

At each time interval the cumulative \% mortality was calculated following the method of Lloyd (1979). This value (expressed as probits) was plotted as a function of time (expressed logarithmically) directly onto logarithmic-probability graph paper for each of the concentrations of metal used. A straight line was fitted by eye to each set of data, giving greater weight to those values between 25 and $75 \%$ response. The time for $50 \%$ mortality, the median period of survival $\left(\mathrm{LT}_{50}\right)$, was then read from the graph (Litchfield 1949).

Concentration-response curves were plotted to obtain the median lethal concentration $\left(\mathrm{LT}_{50}\right)$ for the time periods $24,48,96,192$ and $384 \mathrm{~h}$. (The data were sufficiently close to a linear fit not to warrant regression analysis.)

\section{STATISTICAL ANALYSIS}

Three-factor analysis of variance of untransformed $\mathrm{LT}_{50}$ values was partitioned into linear and quadratic effects for the main factors (temperature, concentration, salinity) and their second order interactions. Since there were no replicates, the third order interaction was taken as the error term (Davies 1979). Corophium volutator and Macoma balthica data were analysed separately for each element. Those terms which were significant at $P \leqslant 0.01$ were included in a response surface model for each species. Coefficients for the terms were found by multiple regression and the resulting equations used to draw isopleths of $\mathrm{LT}_{50}$.

As explained in Bryant et al. (1985) for arsenic analyses and previously suggested in Bryant et al. (1984) for chromium analyses, the response surface models were only used to display the significant effects and their interactions in a graphical form. It would be a mistake to assign precise biological meanings to the numerical values of the coefficients or to locate optima of response from the equations. A detailed discussion and improved techniques are given recently by Schnute \& McKinnell (1984).

Table 1. Corophium volutator. Median survival times, $\mathrm{LT}_{\text {so }}(\mathrm{h})$, derived graphically at 5 to $15^{\circ} \mathrm{C}, 5$ to $35 \%$, and nickel concentrations of 2 to $128 \mathrm{ppm}$

\begin{tabular}{|c|c|c|c|c|c|c|c|c|c|c|c|c|c|c|c|}
\hline \multirow{2}{*}{$\begin{array}{l}\text { Concentration } \\
(\mathrm{ppm})\end{array}$} & \multicolumn{5}{|c|}{$5^{\circ} \mathrm{C}$} & \multicolumn{5}{|c|}{$10^{\circ} \mathrm{C}$} & \multicolumn{5}{|c|}{$15^{\circ} \mathrm{C}$} \\
\hline & $5 \%$ & $10 \%$ & $15 \%$ & $25 \%$ & $35 \%$ & $5 \%$ & $10 \%$ & $15 \%$ & $25 \%$ & $35 \%$ & $5 \%$ & $10 \%$ & $15 \%$ & $25 \%$ & $35 \%$ \\
\hline 2 & 140 & $>384$ & $>384$ & $>384$ & $>384$ & 190 & $>384$ & $>384$ & 330 & $>384$ & 130 & 280 & 270 & 330 & 260 \\
\hline 4 & 115 & 280 & $>384$ & $>384$ & 380 & 145 & 350 & 290 & 300 & 300 & 110 & 210 & 195 & 180 & 300 \\
\hline 8 & 100 & 240 & 250 & 160 & 320 & 110 & 190 & 260 & 230 & 230 & 96 & 125 & 245 & 200 & 220 \\
\hline 16 & 50 & 155 & 105 & 180 & 220 & 66 & 90 & 175 & 170 & 200 & 85 & 120 & 120 & 150 & 150 \\
\hline 32 & 40 & 96 & 40 & 115 & 155 & 29 & 68 & 70 & 68 & 140 & 50 & 96 & 72 & 86 & 130 \\
\hline 64 & 32 & 50 & 30 & 76 & 68 & 19 & 23 & 50 & 50 & 90 & 34 & 42 & 54 & 62 & 72 \\
\hline 128 & 16 & 24 & 28 & 42 & 58 & 8 & 12 & 19 & 25 & 40 & 20 & 19.5 & 26 & 33 & 36 \\
\hline
\end{tabular}



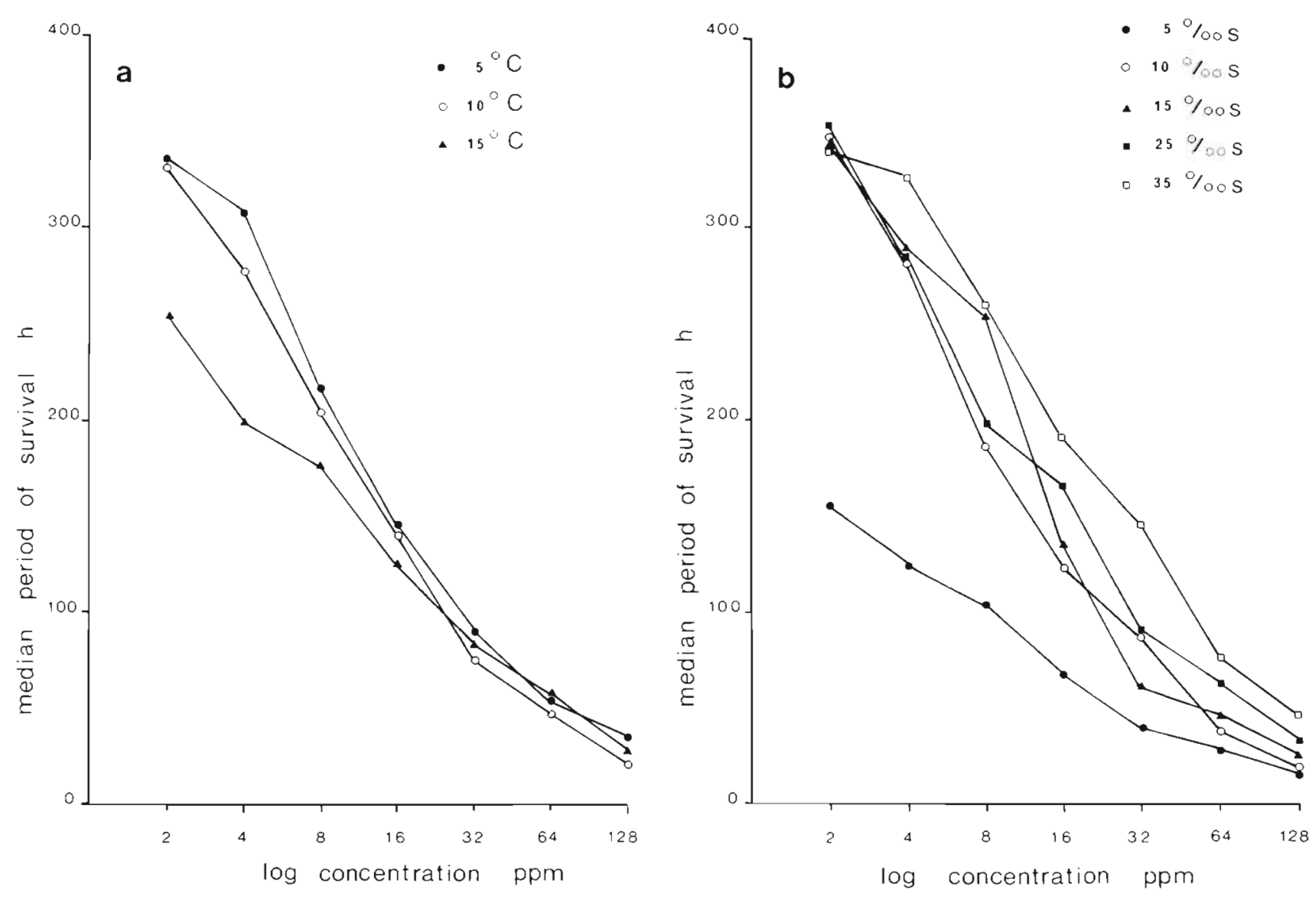

Fig. 1. Corophium volutator. Change in median survival time, $\mathrm{LT}_{50}$ (h), with increasing concentration of nickel at: (a) 3 temperatures; (b) 5 salinities

\section{RESULTS}

\section{Nickel and Corophium volutator}

Median survival time $\left(\mathrm{LT}_{50}\right)$ of Corophium volutator decreased for all experimental conditions with increasing nickel concentration (Table 1; Fig. 1). The combined effect of temperature and salinity levels on median survival time at one nickel concentration, 64 ppm (Fig. 2) shows maximum survival at low temperature and high salinity levels. At all levels of temperature and nickel concentration, increasing the salinity level increased median survival time, though the effect of temperature on the response to nickel toxicity was not as strong as that for salinity. Median survival time was lower at $15^{\circ} \mathrm{C}$ than at $5^{\circ} \mathrm{C}$, particularly at low levels of nickel concentration, but at some combinations of salinity and concentration levels, nickel decreased median survival time more at $5^{\circ} \mathrm{C}$ than at $10^{\circ} \mathrm{C}$.

The greater influence of salinity, compared with

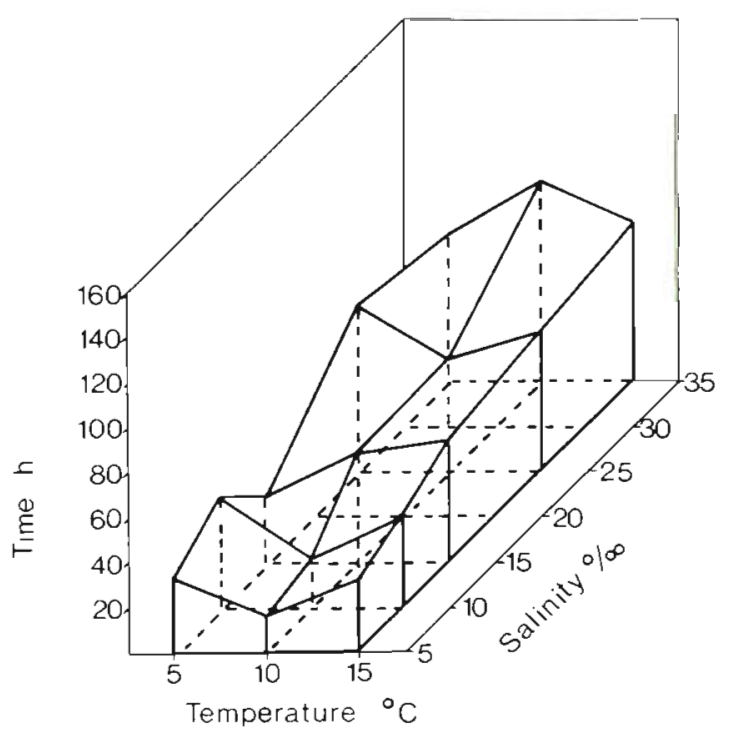

Fig. 2. Corophium volutator. Effect of temperature and salinity on median survival time, $\mathrm{LT}_{50}(\mathrm{~h})$, at $64 \mathrm{ppm}$ nickel concentration 
Table 2. Corophium volutator. Median lethal concentrations, $\mathrm{LC}_{50}$, of nickel (ppm) at 5 to $15^{\circ} \mathrm{C}$ and 5 to $35 \%$ for exposure times of 24 to $192 \mathrm{~h}$

\begin{tabular}{|c|c|c|c|c|c|c|c|c|c|c|c|c|c|c|c|}
\hline \multirow{2}{*}{$\begin{array}{l}\text { Exposure } \\
\text { time }(\mathrm{h})\end{array}$} & \multicolumn{5}{|c|}{$5^{\circ} \mathrm{C}$} & \multicolumn{5}{|c|}{$10^{\circ} \mathrm{C}$} & \multicolumn{5}{|c|}{$15^{\circ} \mathrm{C}$} \\
\hline & $5 \%$ & $10 \%$ & $15 \%$ & $25 \%$ & $35 \%$ & $5 \%$ & $10 \%$ & $15 \%$ & $25 \%$ & $35 \%$ & $5 \%$ & $10 \%$ & $15 \%$ & $25 \%$ & $35 \%$ \\
\hline 24 & 80 & $>128$ & 60 & $>128$ & $>128$ & 46 & 62 & 90 & $>128$ & $>128$ & $>128$ & $>128$ & $>128$ & $>128=$ & $>128$ \\
\hline 48 & 20 & 60 & 31 & 100 & $>128$ & 18 & 30 & 46 & 56 & 160 & 30.0 & 50 & 54 & $65>$ & $>128$ \\
\hline 96 & 5 & 21 & 18 & 36 & 54 & 8 & 15 & 22 & 24 & 52 & 5.6 & 16 & 18 & 22 & 34 \\
\hline 192 & $\cdot$ & 7 & 9.5 & 15 & 16 & 3.2 & 7.0 & 11 & 8.5 & 16 & $\cdot$ & • & 5 & 7.2 & 7.5 \\
\hline
\end{tabular}

Table 3. Corophium volutator. Analysis of variance of effects of $\$$ nickel concentrations, 5 salinities and 3 temperatures on median survival times. DF: degrees of freedom; MS: mean sum of squares; F: ratio of treatment mean square to error mean square

\begin{tabular}{|c|c|c|c|c|}
\hline Source of variation & DF & MS & $F$ & \\
\hline \multicolumn{5}{|l|}{ Temperature } \\
\hline $\mathrm{T}$ & 1 & 22,700 & 8.19 & $\cdots$ \\
\hline $\mathrm{T}^{2}$ & 1 & 1,193 & 0.43 & NS \\
\hline \multicolumn{5}{|l|}{ Concentration } \\
\hline $\mathrm{C}$ & 1 & 675,600 & 243.99 & $\cdots$ \\
\hline $\mathrm{C}^{2}$ & 1 & 256,300 & 92.56 & $\cdots$ \\
\hline \multicolumn{5}{|l|}{ Salinity } \\
\hline $\mathrm{S}$ & 1 & 120,700 & 43.59 & $\cdots$ \\
\hline$S^{2}$ & 1 & 24,000 & 8.67 & $\cdots$ \\
\hline \multicolumn{5}{|l|}{ Temperature $\times$ concentration } \\
\hline $\mathrm{TC}$ & 1 & 10,120 & 3.65 & NS \\
\hline $\mathrm{T}^{2} \mathrm{C}$ & 1 & 3,148 & 1.14 & NS \\
\hline$T C^{2}$ & 1 & 9,667 & 3.49 & NS \\
\hline $\mathrm{T}^{2} \mathrm{C}^{2}$ & 1 & 2,056 & 0.74 & NS \\
\hline \multicolumn{5}{|l|}{ Temperature $\times$ salinity } \\
\hline TS & 1 & 4,728 & 1.71 & NS \\
\hline $\mathrm{T}^{2} \mathrm{~S}$ & 1 & 442.7 & 0.16 & NS \\
\hline $\mathrm{TS}^{2}$ & 1 & 681.9 & 0.25 & NS \\
\hline$T^{2} S^{2}$ & 1 & 81.69 & 0.03 & NS \\
\hline \multicolumn{5}{|l|}{ Concentration $\times$ salinity } \\
\hline $\mathrm{CS}$ & 1 & 17,880 & 6.46 & $\cdot$ \\
\hline$C^{2} S$ & 1 & 2,113 & 0.76 & NS \\
\hline $\mathrm{CS}^{2}$ & 1 & 14,330 & 5.18 & $\cdot$ \\
\hline$C^{2} S^{2}$ & 1 & 11,670 & 4.21 & $\cdot$ \\
\hline Temperature $\times$ concentration $\times$ salinity (error) & 86 & $2,768.9$ & & \\
\hline Total & 104 & & & \\
\hline
\end{tabular}

temperature, on the lowering of median survival time by increasing nickel concentration is demonstrated by the median lethal concentrations $\left(\mathrm{LC}_{50}\right)$ of nickel to Corophium volutator (Table 2). An increase from 5 to $35 \%$ resulted in at least a 5 -fold increase in median lethal concentration, whereas a decrease in tempera- ture from 15 to $5^{\circ} \mathrm{C}$ resulted in no more than a 2 -fold increase in median lethal concentration.

The analysis of variance of median survival times for Corophium volutator (Table 3) shows that the linear effects of temperature, concentration and salinity, and the quadratic effect of both concentration and salinity, 
Table 4. Macoma balthica. Median survival times $\mathrm{LT}_{50}$ (h), derived graphically at 5 to $15^{\circ} \mathrm{C}, 15$ to $35 \%$, and nickel concentrations of 16 to $2000 \mathrm{ppm}$

\begin{tabular}{|c|c|c|c|c|c|c|c|c|c|}
\hline \multirow{2}{*}{$\begin{array}{l}\text { Concentration } \\
\qquad(\mathrm{ppm})\end{array}$} & \multicolumn{3}{|c|}{$5^{\circ} \mathrm{C}$} & \multicolumn{3}{|c|}{$10^{\circ} \mathrm{C}$} & \multicolumn{3}{|c|}{$15^{\circ} \mathrm{C}$} \\
\hline & $15 \%$ & $25 \%$ & $35 \%$ & $15 \%$ & $25 \%$ & $35 \%$ & $15 \%$ & $25 \%$ & $35 \%$ \\
\hline 16 & 350 & $>384$ & $>384$ & $>384$ & $>384$ & $>384$ & 280 & $>384$ & $>384$ \\
\hline 32 & 180 & $>384$ & $>384$ & 230 & $>384$ & $>384$ & 68 & $>384$ & $>384$ \\
\hline 64 & 150 & 330 & $>384$ & 115 & $>384$ & $>384$ & 76 & 240 & 280 \\
\hline 128 & 115 & 260 & $>384$ & 85 & 230 & $>384$ & 68 & 150 & 280 \\
\hline 256 & 62 & 130 & 220 & 53 & 130 & 310 & 48 & 64 & 220 \\
\hline 512 & 36 & 76 & 135 & 33 & 80 & 145 & 27 & 36 & 80 \\
\hline 1000 & 20 & 58 & 60 & 40 & 80 & 90 & 12 & 24 & 70 \\
\hline 2000 & 7.5 & 22 & 42 & 20 & 60 & 60 & 7.5 & 14 & 35 \\
\hline
\end{tabular}

significantly $(P<0.01)$ affected median survival times. None of the possible 2-way interactions significantly affected $\mathrm{LT}_{50}$ values $(P>0.01)$. The response surface equation was:

$$
\begin{gathered}
\mathrm{LT}_{50}=203.1-3.6 \mathrm{~T}-6.266 \mathrm{C}+0.0345 \mathrm{C}^{2}+9.93 \mathrm{~S} \\
\quad-0.1681 \mathrm{~S}^{2} \\
\left(R^{2}=76.5 \% ; F=16.15 ; \mathrm{df}=5.99 ; P<0.001\right)
\end{gathered}
$$

where $\mathrm{T}=$ temperature $\left({ }^{\circ} \mathrm{C}\right) ; \mathrm{C}=$ concentration of the metal (ppm); $\mathrm{S}=$ salinity $(\%)$. The $\mathrm{C}$ and $\mathrm{C}^{2}$ terms together approximate a hyperbolic decrease in $\mathrm{LT}_{50}$ with concentration. An optimum in $\mathrm{LT}_{50}$ with concen- tration is not inferred. (These points of interpretation also apply to the other species and metal combinations below.) For C. volutator with nickel, no interactions are significant and therefore isopleth diagrams are not needed.

\section{Nickel and Macoma balthica}

For Macoma balthica an increase in the level of concentration of nickel resulted in decreased median survival times under all experimental conditions
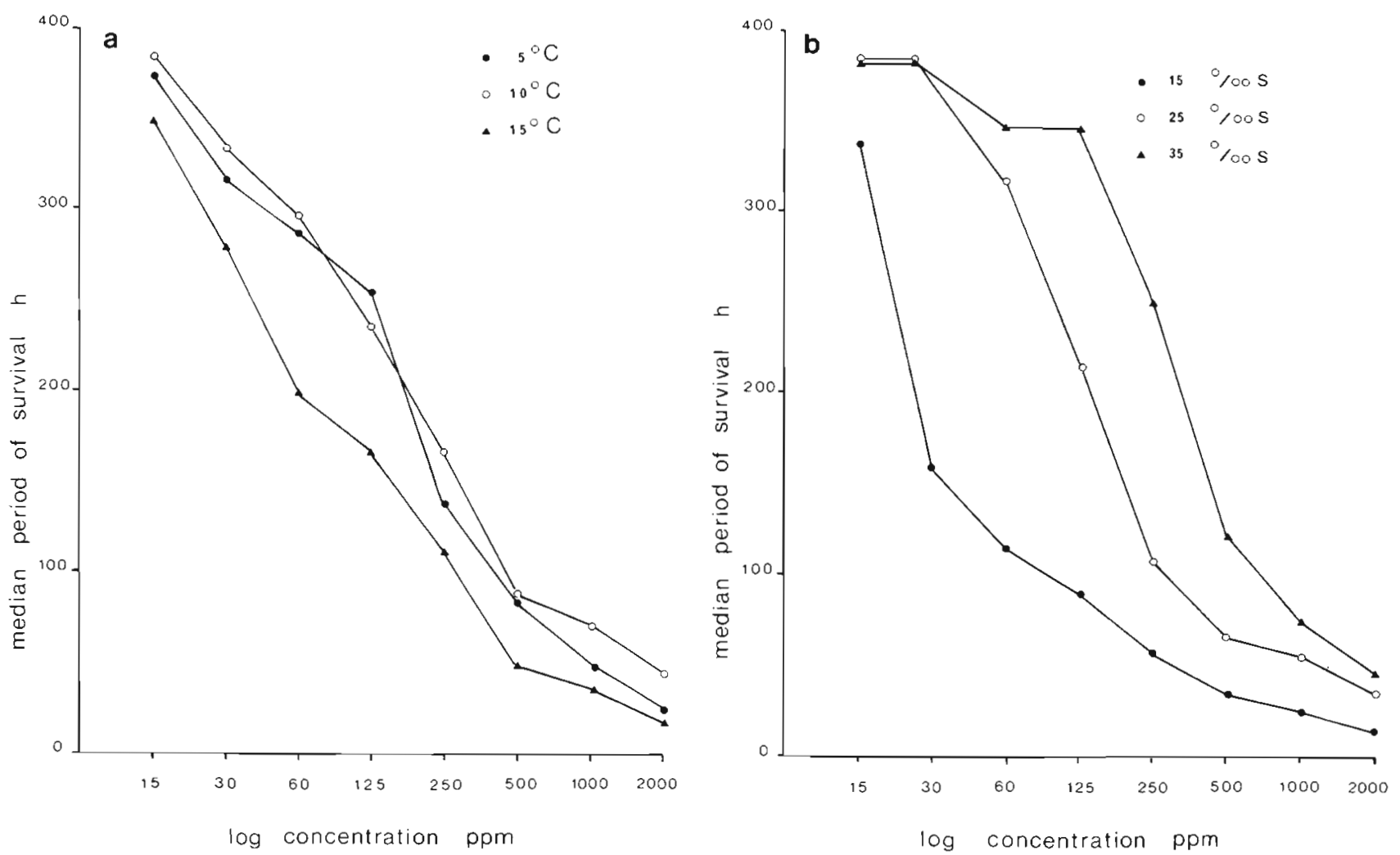

Fig. 3. Macoma balthica. Change in median survival time, $L T_{50}(\mathrm{~h})$, with increasing concentration of nickel at: (a) 3 temperatures; (b) 3 salinities 


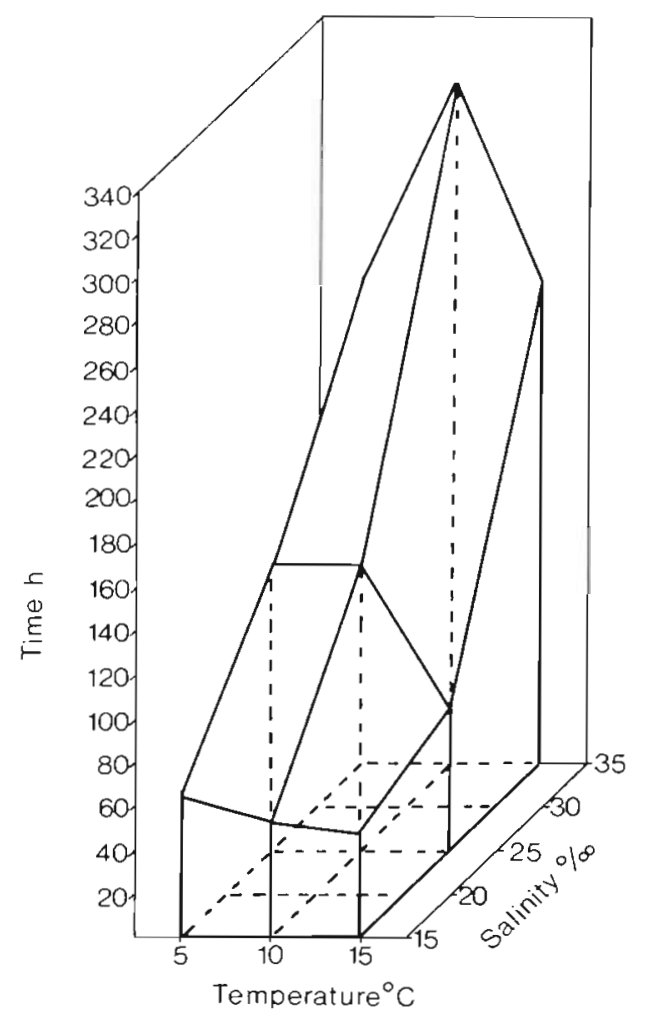

Fig. 4. Macoma balthica. Effect of temperature and salinity on median survival time, $\mathrm{LT}_{\text {SO }}$ (h), at $256 \mathrm{ppm}$ nickel concentration

(Table 4; Fig. 3). The combined effect of temperature and salinity levels on median survival time at one nickel concentration, $256 \mathrm{ppm}$ (Fig. 4), shows greatest sensitivity to nickel is occurring at low salinity. The median survival time at each salinity level was greater at 5 than at $15^{\circ} \mathrm{C}$, though there was little difference at 5 and $10^{\circ} \mathrm{C}$.

This pattern of response to nickel was reflected by the median lethal concentrations $\left(\mathrm{LC}_{50}\right)$ for Macoma balthica (Table 5) with changes in salinity exerting greater effects than changes in temperature.

The effect of temperature on median survival time $\left(\mathrm{LT}_{50}\right)$ of Macoma balthica is insignificant $(P>0.01)$ by the analysis of variance (Table 6). The linear effect of nickel concentration and salinity, and the quadratic effect of concentration all had highly significant $(P<0.01)$ effects on median survival time. The linearlinear interaction between concentration and salinity was also significant $(P<0.01)$, indicating that the effect of concentration was altered with the level of salinity and vice versa. The response surface equation was:

$$
\begin{aligned}
& \mathrm{LT}_{50}= 73.2-0.3756 \mathrm{C}+0.0000177 \mathrm{C}^{2}+9.33 \mathrm{~S} \\
&-0.00447 \mathrm{CS} \\
&\left(R^{2}=78.7 \% ; F=14.19 ; \mathrm{df}=4.67 ; P<0.001\right)
\end{aligned}
$$

Fig. 5 shows the response surface isopleths representing the combined effects of nickel concentration and salinity on median survival times for Macoma balthica at $5^{\circ} \mathrm{C}$. Maximum survival times occur at high salinities and low concentrations. As salinity increases, the effect of concentration of nickel is progressively increased. This is demonstrated by the increasing steepness of the contours with increasing nickel concentration. A given increase in concentration reduces $\mathrm{LT}_{50}$ less at lower salinities than at higher salinities and hence the negative sign of the coefficient of the concentration-salinity interaction, i.e. higher salinities antagonize the metal's effect. The isopleths generated at 5,10 and $15^{\circ} \mathrm{C}$ were the same, as no significant temperature term was included in the response surface model.

\section{Zinc and Corophium volutator}

Increase in the concentration of zinc decreased median survival time $\left(\mathrm{LT}_{50}\right)$ for Corophium volutator under all experimental conditions (Table 7; Fig. 6). Maximum median survival time occurred at low temperature and high salinity. The combined effect of temperature and salinity on the median survival time of $C$. volutator at one zinc concentration, $4 \mathrm{ppm}$, is shown in Fig. 7.

For Corophium volutator at all salinities and temperatures the median lethal concentration decreased as exposure time was increased (Table 8). Increased salinity increased the median lethal concentration, but the temperature effect was less clear as there was a

\begin{tabular}{|c|c|c|c|c|c|c|c|c|c|}
\hline \multirow{2}{*}{$\begin{array}{c}\text { Exposure } \\
\text { time (h) }\end{array}$} & \multicolumn{3}{|c|}{$5^{\circ} \mathrm{C}$} & \multicolumn{3}{|c|}{$10^{\circ} \mathrm{C}$} & \multicolumn{3}{|c|}{$15^{\circ} \mathrm{C}$} \\
\hline & $15 \%$ & $25 \%$ & $35 \%$ & $15 \%$ & $25 \%$ & $35 \%$ & $15 \%$ & $25 \%$ & $35 \%$ \\
\hline 24 & 850 & 1750 & $>2000$ & 750 & $>2000$ & $>2000$ & 540 & 950 & $>2000$ \\
\hline 48 & 300 & 800 & 1600 & 260 & 1600 & $>2000$ & 300 & 400 & $>2000$ \\
\hline 96 & 100 & 380 & 700 & 95 & 560 & 1100 & 110 & 180 & 540 \\
\hline 192 & 36 & 180 & 300 & 36 & 180 & 450 & 48 & 80 & 140 \\
\hline
\end{tabular}

Table 5. Macoma balthica. Median lethal concentrations, $\mathrm{LC}_{50}$ of nickel (ppm) at 5 to $15^{\circ} \mathrm{C}$ and 15 to $35 \%$ for exposure times of 24 to $192 \mathrm{~h}$ 
Table 6. Macoma balthica. Analysis of variance of effects of 8 nickel concentrations, 3 salinities and 3 temperatures on median survival times. DF: degrees of freedom; MS: mean sum of squares; $F$ : ratio of treatment mean square to error mean square

\begin{tabular}{|c|c|c|c|c|}
\hline Source of variation & DF & MS & $F$ & \\
\hline \multicolumn{5}{|l|}{ Temperature } \\
\hline $\mathrm{T}$ & 1 & 18,490 & 4.18 & $\cdot$ \\
\hline $\mathrm{T}^{2}$ & 1 & 15,480 & 3.50 & $\cdot$ \\
\hline \multicolumn{5}{|l|}{ Concentration } \\
\hline $\mathrm{C}$ & 1 & 624,900 & 141.20 & $\cdots$ \\
\hline$C^{2}$ & 1 & 270,000 & 61.00 & $\cdots$ \\
\hline \multicolumn{5}{|l|}{ Salinity } \\
\hline $\mathrm{S}$ & 1 & 240,800 & 54.41 & $\cdots$ \\
\hline $\mathrm{S}^{2}$ & 1 & 7,084 & 1.60 & NS \\
\hline \multicolumn{5}{|l|}{ Temperature $\times$ concentration } \\
\hline $\mathrm{TC}$ & 1 & 3,937 & 0.89 & NS \\
\hline $\mathrm{T}^{2} \mathrm{C}$ & 1 & 149.8 & 0.03 & NS \\
\hline $\mathrm{TC}^{2}$ & 1 & 343.8 & 0.08 & NS \\
\hline $\mathrm{T}^{2} \mathrm{C}^{2}$ & 1 & 28.72 & 0.01 & NS \\
\hline \multicolumn{5}{|l|}{ Temperature $\times$ salinity } \\
\hline TS & 1 & 171.1 & 0.04 & NS \\
\hline $\mathrm{T}^{2} \mathrm{~S}$ & 1 & 213.0 & 0.05 & NS \\
\hline $\mathrm{TS}^{2}$ & 1 & 108.4 & 0.02 & NS \\
\hline $\mathrm{T}^{2} \mathrm{~S}^{2}$ & 1 & 21.67 & 0.00 & NS \\
\hline \multicolumn{5}{|l|}{ Concentration $\times$ salinity } \\
\hline $\mathrm{CS}$ & 1 & 40,140 & 9.07 & $\cdots$ \\
\hline $\mathrm{C}^{2} \mathrm{~S}$ & 1 & 3,642 & 0.82 & NS \\
\hline $\mathrm{CS}^{2}$ & 1 & 3,932 & 0.89 & NS \\
\hline$C^{2} S^{2}$ & 1 & 6,913 & 1.56 & NS \\
\hline Temperature $\times$ concentration $\times$ salinity (error) & 53 & 4.425 .94 & & \\
\hline Total & 71 & & & \\
\hline
\end{tabular}

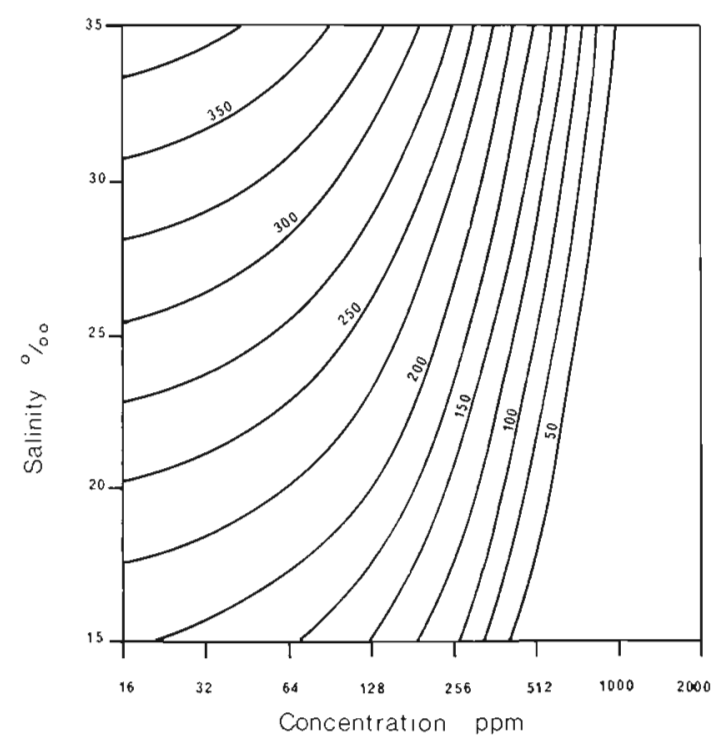

Fig. 5. Macoma balthica. Response surface showing combined effect of nickel concentration and salinity on median survival time, $\mathrm{LT}_{50}(\mathrm{~h})$, at $5^{\circ} \mathrm{C}$ greater difference between median lethal concentrations at 10 and $15^{\circ} \mathrm{C}$ than between those at 5 and $10^{\circ} \mathrm{C}$.

Analysis of variance of median survival times for Corophium volutator exposed to zinc (Table 9) shows that the linear effects of temperature, concentration and salinity, and the quadratic effect of concentration all significantly influence median survival time. The linear-linear interaction between concentration and salinity had a significant effect $(P<0.01)$ on median survival time. The response equation was:

$$
\begin{gathered}
\mathrm{LT}_{50}=135.9-4.51 \mathrm{~T}-3.146 \mathrm{C}+0.02165 \mathrm{C}^{2} \\
\quad+3.345 \mathrm{~S}-0.0307 \mathrm{CS} \\
\left(R^{2}=54.8 \% ; \mathrm{F}=13.49 ; \mathrm{df}=5.114 ; P<0.001\right)
\end{gathered}
$$

The interaction between zinc concentration and salinity (Fig. 8) shows maximum survival times occurring at high salinities and low concentrations. A given increase in concentration reduces median survival time less at low salinities than at high salinities. The sign of this interaction term is negative in the response 
Table 7. Corophium volutator. Median survival times, $\mathrm{LT}_{50}(\mathrm{~h})$, derived graphically at 5 to $15^{\circ} \mathrm{C}, 5$ to $35 \%$ and zinc concentrations of 1 to $128 \mathrm{ppm}$

\begin{tabular}{|c|c|c|c|c|c|c|c|c|c|c|c|c|c|c|c|}
\hline \multirow{2}{*}{$\begin{array}{l}\text { Concentration } \\
\text { (ppm) }\end{array}$} & \multicolumn{5}{|c|}{$5^{\circ} \mathrm{C}$} & \multicolumn{5}{|c|}{$10^{\circ} \mathrm{C}$} & \multicolumn{5}{|c|}{$15^{\circ} \mathrm{C}$} \\
\hline & $5 \%$ & $10 \%$ & $15 \%$ & $25 \%$ & $35 \%$ & $5 \%$ & $10 \%$ & $15 \%$ & $25 \%$ & $35 \%$ & $5 \%$ & $10 \%$ & $15 \%$ & $25 \%$ & $35 \%$ \\
\hline 1 & 90 & 270 & 330 & $>384$ & $>384$ & 100 & 115 & 320 & $>384$ & 220 & 96 & 160 & 180 & 210 & 150 \\
\hline 2 & 80 & 145 & 165 & 270 & 300 & 66 & 60 & 145 & 320 & 160 & 78 & 70 & 120 & 130 & 120 \\
\hline 4 & 68 & 105 & 120 & 160 & 220 & 58 & 70 & 135 & 160 & 155 & 48 & 90 & 68 & 100 & 110 \\
\hline 8 & 60 & 60 & 110 & 120 & 180 & 54 & 60 & 58 & 96 & 130 & 58 & 70 & 52 & 76 & 76 \\
\hline 16 & 56 & 56 & 60 & 85 & 115 & 44 & 42 & 70 & 80 & 85 & 35 & 48 & 38 & 42 & 60 \\
\hline 32 & 50 & 44 & 42 & 58 & 64 & 50 & 34 & 50 & 56 & 80 & 33 & 38 & 44 & 34 & 48 \\
\hline 64 & 35 & 22 & 26 & 38 & 37 & 35 & 27 & 35 & 38 & 52 & 20 & 33 & 35 & 24 & 46 \\
\hline 128 & 23 & 22 & 23 & 32 & 33 & 31 & 23 & 26 & 30 & 48 & 12 & 20 & 21 & 23 & 24 \\
\hline
\end{tabular}

surface equation, indicating the antagonistic effect of salinity on the effect of concentration.

\section{Zinc and Macoma balthica}

For Macoma balthica median survival times decreased with increasing zinc concentration (Table 10; Fig. 9). Increasing salinity and decreasing temperature increased median survival time, and Fig. 10 shows the combined effects of ternperature and salinity on median survival time at one zinc concentration, $250 \mathrm{ppm}$. The temperature effect was generally less consistent than the salinity effect, as the median survival times were greater at 10 than $5^{\circ} \mathrm{C}$ for some experimental combinations.

Median lethal concentrations, $\mathrm{LC}_{50}$, (Table 11) reveal that for both $48 \mathrm{~h}$ and $96 \mathrm{~h}$ periods of exposure zinc was most toxic at $15^{\circ} \mathrm{C}$ and least toxic at $10^{\circ} \mathrm{C}$; $\mathrm{LC}_{50}$ values at $5^{\circ} \mathrm{C}$ were intermediate. All $\mathrm{LC}_{50}$ values decreased as exposure time increased, as was found for Corophium volutator.

Analysis of variance of median survival times indicates that the linear effects of temperature, concentration and salinity, and the quadratic effects of temperature and concentration had a highly significant
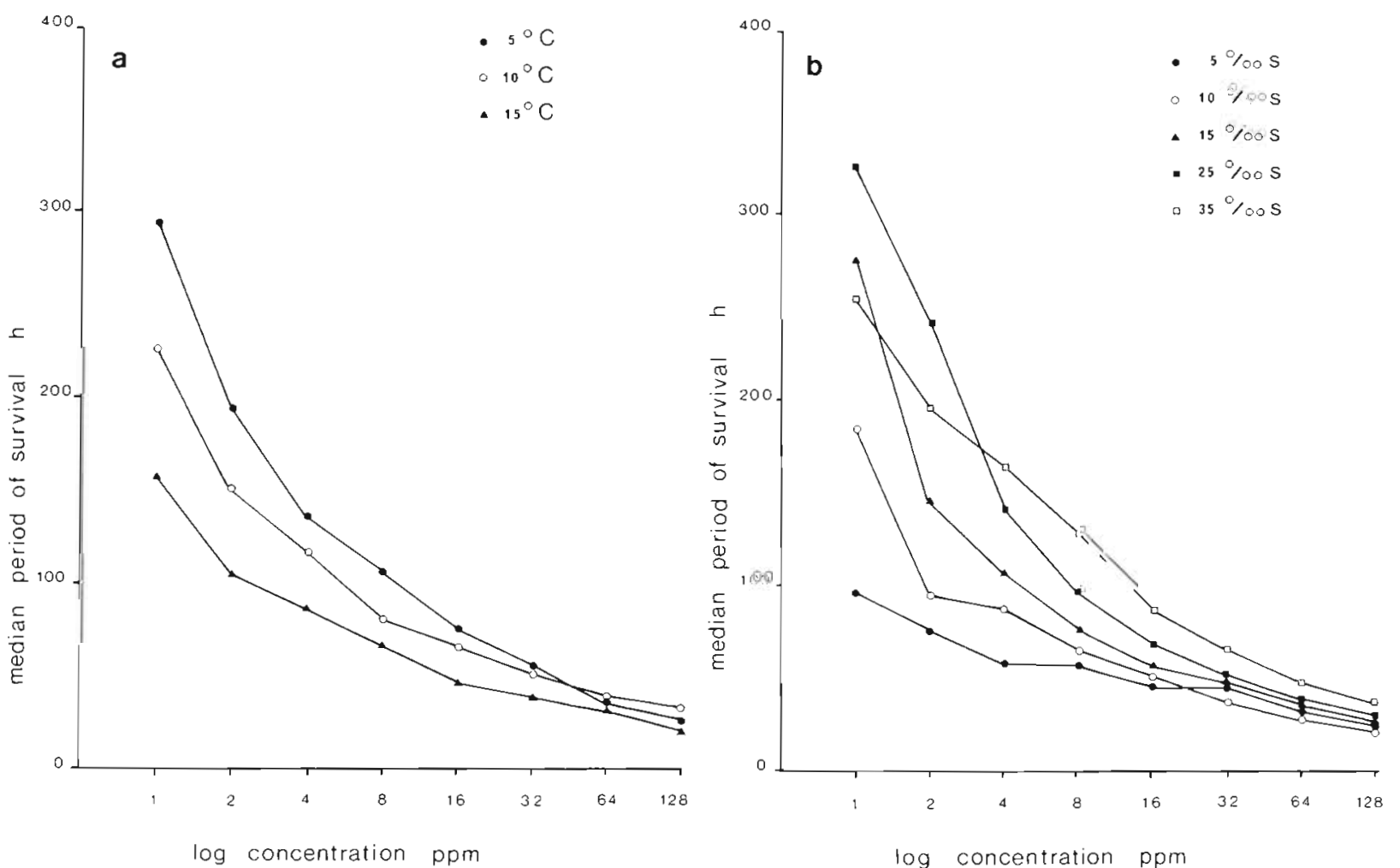

Fig. 6. Corophium volutator. Change in median survival time, $\operatorname{LT}_{50}(\mathrm{~h}$ ), with increasing concentration of zinc at: (a) 3 temperatures; (b) 5 salinities 


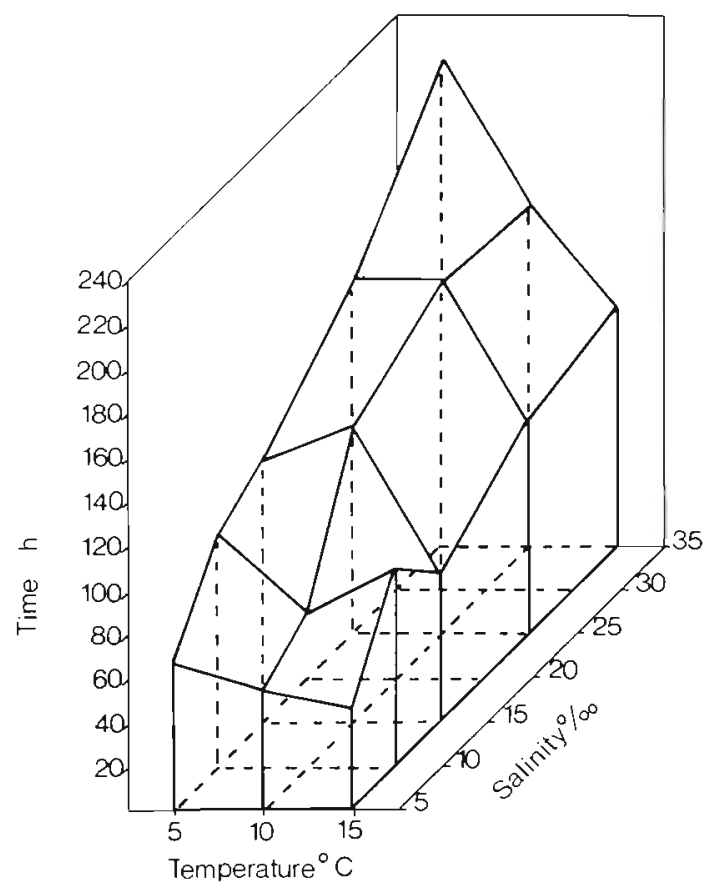

Fig. 7. Corophium volutator. Effects of temperature and salinity on median survival time, $\mathrm{LT}_{50}(\mathrm{~h})$, at $4 \mathrm{ppm}$ zinc concentration

$(P<0.01)$ influence on median survival time (Table 12). All 3 of the linear-linear interaction terms were significant, $(P<0.01)$ : temperature and concentration, temperature and salinity, and concentration and salinity. The response surface equation was:

$\mathrm{LT}_{50}=-113.2+27.94 \mathrm{~T}-1.202 \mathrm{~T}^{2}-0.1599 \mathrm{C}+$ $0.0000548 \mathrm{C}^{2}+11.76 \mathrm{~S}+0.00554 \mathrm{TC}-0.529 \mathrm{TS}-$

$$
0.003396 \mathrm{CS}
$$

$\left(R^{2}=87.9 \% ; F=7.92, \mathrm{df}=8.63 ; P<0.001\right)$.

The interactive effect of concentration and salinity on median survival times at $5^{\circ} \mathrm{C}$ is shown in Fig. 11 . Here again, a given increase in concentration of zinc reduces median survival time less at low salinities than at high salinities, with a negative sign for this interaction term in the equation, i.e. increased salinity antagonizes the effect of the metal. The isopleths generated for 5,10 and $10^{\circ} \mathrm{C}$ were of a similar pattern.

The effect of zinc concentration and temperature on median survival time for Macoma balthica at $25 \%$ is shown in Fig. 12 which is a very different pattern of isopleths to that for the concentration-salinity response surface. Maximum median survival times are at low concentrations and low temperatures. Here, a given increase in concentration of zinc decreases the median survival time less at high temperatures than at low temperatures and hence this interaction term has a positive sign in the response surface equation. Increased temperature therefore ameliorates the effect of concentration.

Lastly, the interactive effect of temperature and salinity on median survival time at one concentration, 15 ppm, zinc (Fig. 13) shows that a given increase in temperature reduces the median survival time far less at low salinities than at high salinities. Therefore increased salinity antagonizes the effect of temperature.

\section{DISCUSSION}

Concentration, temperature and salinity all significantly affect the median survival time of Corophium volutator when the toxic metal is nickel or zinc, and Macoma balthica only when the metal is zinc. Temperature does not significantly affect the median survival time of $M$. balthica when exposed to nickel, though concentration of this metal and salinity had significant effects. In general, median survival time for both species is greatest at $35 \%$ and $5{ }^{\circ} \mathrm{C}$.

High salinities antagonize the effects of zinc on median survival time of Corophium volutator and similarly antagonizes the effects of both zinc and nickel on Macoma balthica. On the other hand, low temperature antagonizes the effects of zinc on $M$. balthica. This means that the metals are having their maximal effect in reducing the median survival times of the 2 species when the concentrations are present in their optimal salinity and temperature conditions.

Table 8. Corophium volutator. Median lethal concentrations, $\mathrm{LC}_{50}$, of zinc (ppm) at 5 to $15^{\circ} \mathrm{C}$ and 5 to $35 \%$ for exposure times of 24 to $192 \mathrm{~h}$

\begin{tabular}{|c|c|c|c|c|c|c|c|c|c|c|c|c|c|c|c|}
\hline \multirow{2}{*}{$\begin{array}{c}\text { Exposure } \\
\text { time (h) }\end{array}$} & \multicolumn{5}{|c|}{$5^{\circ} \mathrm{C}$} & \multicolumn{4}{|c|}{$10^{\circ} \mathrm{C}$} & \multicolumn{6}{|c|}{$15^{\circ} \mathrm{C}$} \\
\hline & $5 \%$ & $10 \%$ & $15 \%$ & $25 \%$ & $35 \%$ & $5 \%$ & $10 \%$ & $15 \%$ & $25 \%$ & $35 \%$ & $5 \%$ & $10 \%$ & $15 \%$ & $25 \%$ & $35 \%$ \\
\hline 24 & 128 & 95 & 110 & $>128$ & $>128$ & $>128$ & 100 & $>128$ & $>128$ & $>128$ & 44 & 90 & 90 & 65 & $>128$ \\
\hline 48 & 14 & 20 & 25 & 46 & 54 & 13 & 12 & 31 & 46 & $>128$ & 7 & 17 & 16 & 17 & 27 \\
\hline 96 & 1 & 4.6 & 6.5 & 12 & 16 & • & 1.6 & 8.5 & 11 & 15 & 1.1 & 3.2 & 3.4 & 4.4 & 3.6 \\
\hline 192 & . & 1 & 1.7 & 3 & 4.4 & $\cdot$ & • & 1.9 & 2.7 & 1.7 & - & . & - & 1.1 & - \\
\hline
\end{tabular}


Table 9. Corophium volutator. Analysis of variance of effects of 8 zinc concentrations, 5 salinities and 3 temperatures on median survival times. DF: degrees of freedom; MS: mean sum of squares; F: ratio of treatment mean square to error mean square

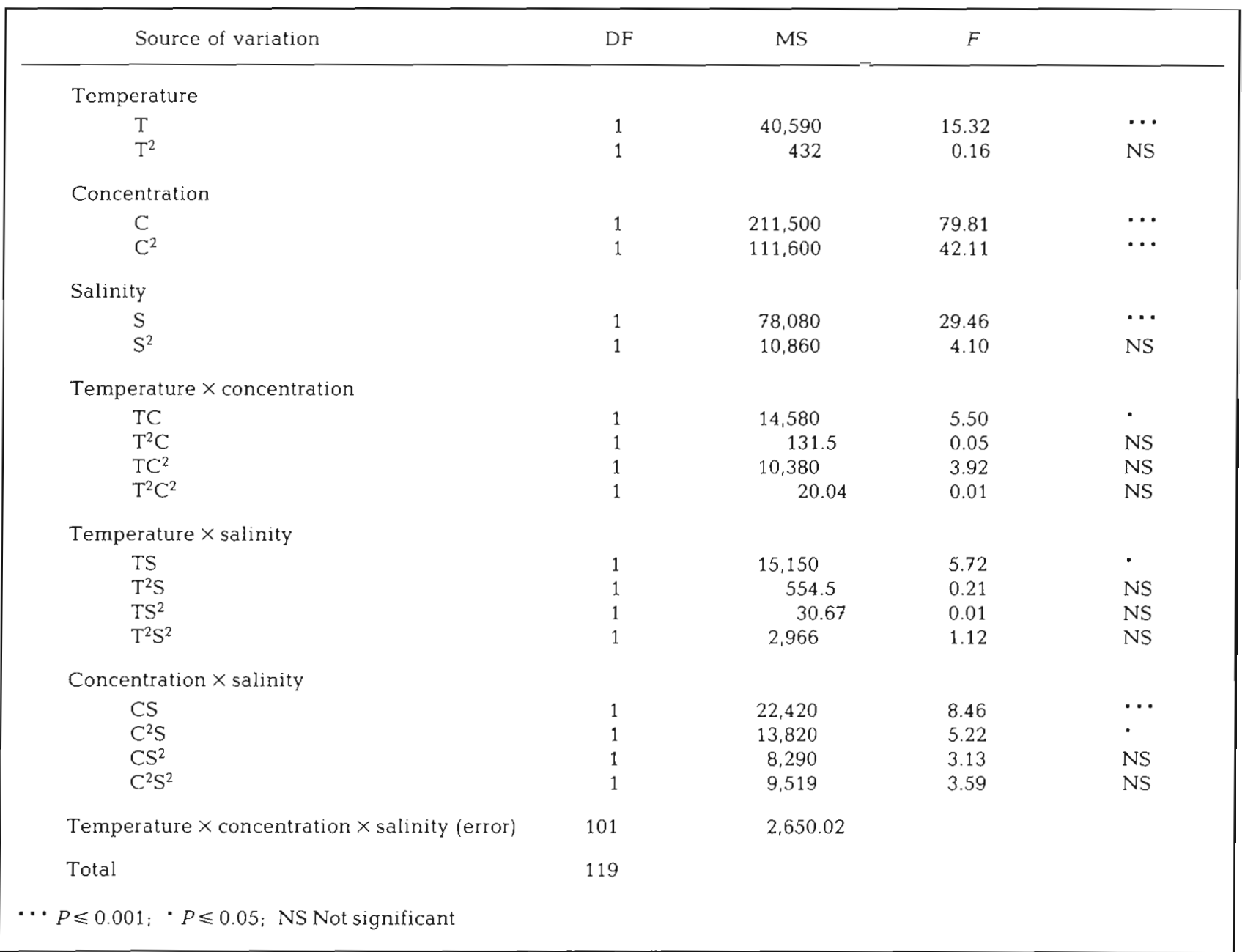

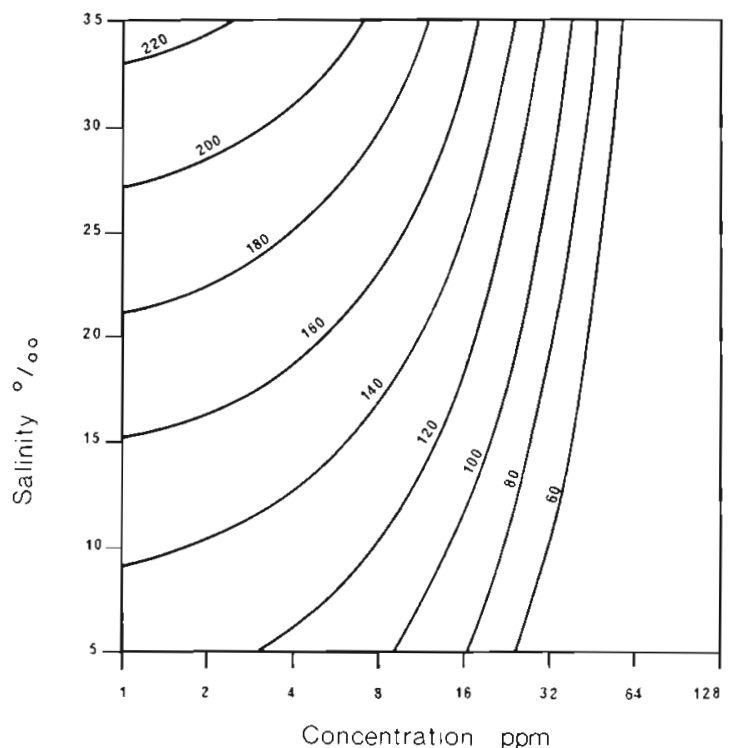

Fig. 8. Corophium volutator. Response surface showing combined effect of zinc concentration and salinity on median survival time, $\operatorname{LT}_{50}(\mathrm{~h})$, at $5^{\circ} \mathrm{C}$
Variances accounted for by the multiple regression analyses of median survival times were: for Macoma balthica, $88 \%$ for zinc, $79 \%$ for nickel; for Corophium volutator, $77 \%$ for nickel, indicating that the descriptive models provided a fair fit for the test results and that they each represent a reasonable predictive model of the effect of the environmental variables and metal concentration on median survival time. However, only $55 \%$ of the variance was accounted for by the analysis of the median survival times of $C$. volutator, for zinc, leaving nearly half of the variance unexplained. In previous work on the toxicity of chromium and arsenic to these 2 species using similar experimental designs (Bryant et al. 1984, 1985), at least $75 \%$ of the variance was accounted for, except in the case of $C$. volutator exposed to arsenic where $68 \%$ of the variance was explained. The high unexplained variance in the experiments with $C$. volutator is unlikely to be due to experimental error as all the experiments were designed and conducted in the same way but it may be 
Table 10. Macoma balthica. Median survival times, LT $_{50}(\mathrm{~h})$, derived graphically at 5 to $15^{\circ} \mathrm{C}, 15$ to $35 \%$ and zinc concentrations of 15 to $2000 \mathrm{ppm}$

\begin{tabular}{|c|c|c|c|c|c|c|c|c|c|}
\hline \multirow{2}{*}{$\begin{array}{c}\text { Concentration } \\
\text { (ppm) }\end{array}$} & \multicolumn{3}{|c|}{$5^{\circ} \mathrm{C}$} & \multicolumn{3}{|c|}{$10^{\circ} \mathrm{C}$} & \multicolumn{3}{|c|}{$15^{\circ} \mathrm{C}$} \\
\hline & $15 \%$ & $25 \%$ & $35 \%$ & $15 \%$ & $25 \%$ & $35 \%$ & $15 \%$ & $25 \%$ & $35 \%$ \\
\hline 15 & 130 & 240 & 290 & 135 & 210 & 300 & 100 & 135 & 180 \\
\hline 30 & 145 & 170 & 330 & 130 & 205 & 276 & 86 & 115 & 145 \\
\hline 60 & 105 & 220 & 400 & 130 & 230 & 230 & 90 & 130 & 135 \\
\hline 125 & 80 & 200 & 380 & 120 & 180 & 216 & 88 & 105 & 140 \\
\hline 250 & 85 & 115 & 240 & 85 & 150 & 185 & 64 & 100 & 125 \\
\hline 500 & 58 & 120 & 130 & 130 & 125 & 145 & 33 & 76 & 90 \\
\hline 1000 & 18.5 & 95 & 70 & 80 & 115 & 96 & 14 & 38 & 40 \\
\hline 2000 & 4.6 & 24 & 18 & 20 & 50 & 58 & 8 & 42 & 13 \\
\hline
\end{tabular}

due to an inherent variability in the response of $C$. volutator to arsenic and zinc compared to $M$. balthica, caused perhaps by factors such as the moult cycle in the crustacean.

Corophium volutator is more sensitive to nickel and zinc than Macoma balthica, and median lethal concentrations $\left(\mathrm{LC}_{50}\right)$ values for $M$. balthica are an order of magnitude greater than those for $C$. volutator. This taxonomic ranking of toxicity is in agreement with the results of Eisler \& Hennekey (1977) who reported $96 \mathrm{~h}$ $\mathrm{LC}_{50}$ values for nickel and zinc 10 times greater for the clam Mya arenaria than for the crab Pagurus longicarpus.

An examination of the $96 \mathrm{~h} \mathrm{LC}_{50}$ values for Corophium volutator indicates a rank order of metal toxicity of $\mathrm{Zn}>\mathrm{Cr}>\mathrm{Ni}>$ As and for Macoma balthica, of $\mathrm{Cr}>\mathrm{Zn}>\mathrm{Ni}>$ As (Bryant et al. 1984, 1985). Denton \& Burden-Jones (1982) found that zinc was more toxic than nickel to juvenile banana prawns under a range of different temperatures and salinities, and Portmann (1968) found the same to be true for a variety of marine invertebrates; although Calabrese et
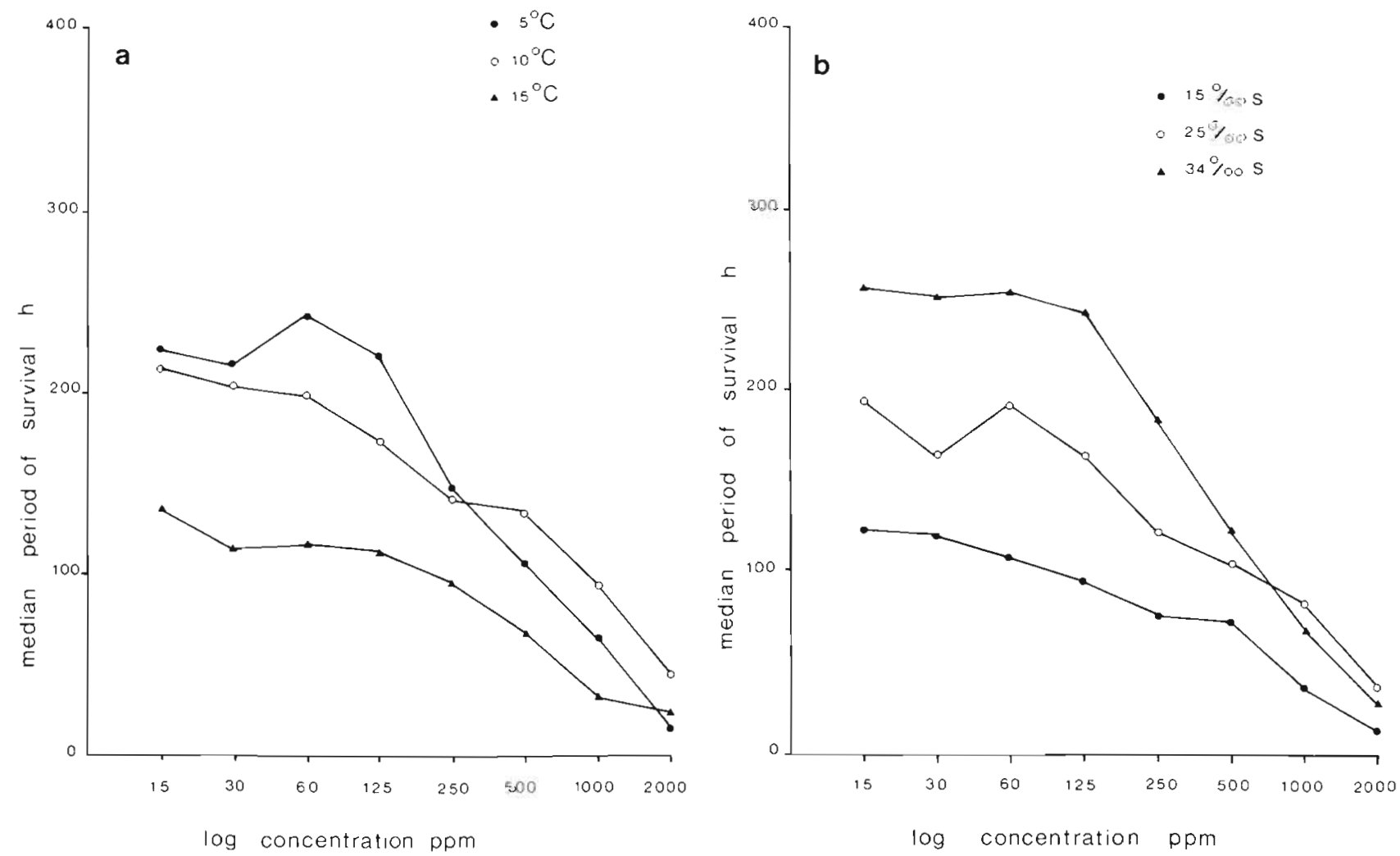

Fig. 9. Macoma balthica. Change in median survival time, $\mathrm{LT}_{50}(\mathrm{~h})$, with increasing concentration of zinc at: (a) 3 temperatures; (b) 3 salinities 


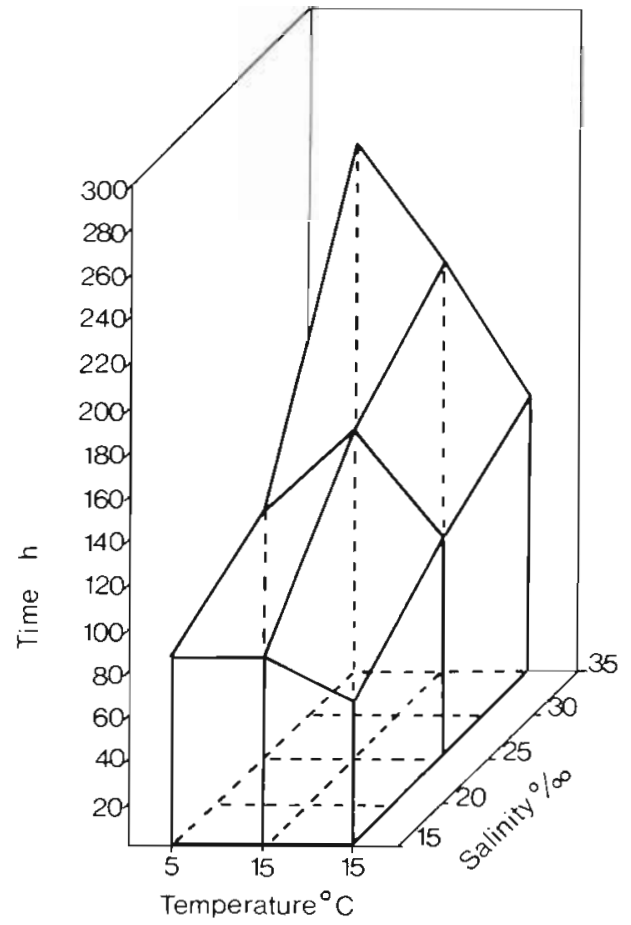

Fig. 10. Macoma balthica. Effects of temperature and salinity on median survival time, $\mathrm{LT}_{50}(\mathrm{~h})$, at $250 \mathrm{ppm}$ zinc concentration

al. (1973) reported a different order of toxicity of $\mathrm{Zn}>\mathrm{As}>\mathrm{Ni}$ for larvae of the american oyster Crassostrea virginica.

All experiments with nickel, and with zinc for Corophium volutator, documented a progressive decrease in toxicity values (as $\mathrm{LC}_{50}$ ) with exposure time, and for these experiments the 'log concentration - log response' curves revealed a straight line relation. Following Lloyd (1979) and Franklin's (1980) suggestions, this indicates that $C$. volutator with zinc and nickel, and $M$. balthica with nickel, have no method of detoxification for these pollutants, so that prolonged exposure to concentrations below that of the $96 \mathrm{~h} \mathrm{LC}_{50}$ will probably be lethal. In the case of $M$. balthica with zinc, a curved relation between 'log concentration - log response' was revealed (Fig. 14), which is believed (Lloyd pers. comm.) to indicate that the toxic substance may have more than one mode of action. Studies by Eldon et al. (1980) on $M$. balthica suggest that zinc attacks the epithelial surface of the foot and siphons, which bear microvilli, and this action coupled with other physiological damage may explain the modes of action of zinc observed.

The $96 \mathrm{~h} \mathrm{LC}_{50}$ values for nickel for Macoma balthica in this study varied from 95 to $1,100 \mathrm{ppm}$ nickel depending on the combination of environmental variables. These are comparable to the values obtained for molluscs by Eisler \& Hennekey (1977) of $72 \mathrm{ppm} \mathrm{Ni}$ for the mud snail Nassarius obsoletus and 320 pprn $\mathrm{Ni}$ for Mya arenaria. The range of $96 \mathrm{~h} \mathrm{LC}_{50}$ values for zinc for Macoma balthica ranged from 60 to $950 \mathrm{ppm}$, the lowest value occurring at combinations of low salinity and high temperature. These values are higher than those reported in the literature for bivalve molluscs which range from $0.166 \mathrm{ppm} \mathrm{Zn}$ for Mercenaria mercenaria (Calabrese \& Nelson 1974) to $7.4 \mathrm{ppm}$ for $M y a$ arenaria (Eisler \& Hennekey 1977). Concentrations for the lethal effect of zinc and nickel are of course higher than those reported for sub-lethal effects. Eldon et al. (1980) described the sub-lethal effects of zinc and nickel on the burrowing activity of $M$. balthica, kept at $6 \%$ and $12{ }^{\circ} \mathrm{C}$. Exposure to concentrations in excess of $2 \mathrm{ppm} \mathrm{Zn}$ and $5 \mathrm{ppm} \mathrm{Ni}$ caused some inhibition of burrowing with complete cessation at $50 \mathrm{ppm} \mathrm{Zn}$ and $20 \mathrm{ppm} \mathrm{Ni}$. Metal concentrations over $1 \mathrm{ppm} \mathrm{Ni}$ and 5 ppm Zn also caused siphon damage. With zinc especially, this damage was limited by closure of the valves, accompanied by strong contraction of the siphons.

The effect of temperature and salinity on the toxicity of zinc to bivalve molluscs is varied. Eisler (1977) found that Mya arenaria was more resistant to zinc at low temperatures, as was found for Macoma balthica in this study. However MacInnes \& Calabrese (1977) reported that the toxicity of zinc to embryos of Crassostrea virginica was not significantly influenced by temperature. Cotter et al. (1982), in a study on the significance of temperature, salinity and zinc as lethal

Table 11. Macoma balthica. Median lethal concentrations $L C_{50}$, of zinc (ppm) at 5 to $15^{\circ} \mathrm{C}$ and 15 to $35 \%$ for exposure times of 24 to $192 \mathrm{~h}$

\begin{tabular}{|c|c|c|c|c|c|c|c|c|c|}
\hline \multirow{2}{*}{$\begin{array}{c}\text { Exposure } \\
\text { time }(\mathrm{h})\end{array}$} & \multicolumn{3}{|c|}{$5^{\circ} \mathrm{C}$} & \multicolumn{3}{|c|}{$10^{\circ} \mathrm{C}$} & \multicolumn{3}{|c|}{$15^{\circ} \mathrm{C}$} \\
\hline & $15 \%$ & $25 \%$ & $35 \%$ & $15 \%$ & $25 \%$ & $35 \%$ & $15 \%$ & $25 \%$ & $35 \%$ \\
\hline 24 & 85 & 190 & 1700 & $>2000$ & $>2000$ & $>2000$ & 700 & $>2000$ & 1400 \\
\hline 48 & 440 & 1400 & 1200 & 1000 & $>2000$ & 2100 & 320 & 1200 & 950 \\
\hline 96 & 140 & 700 & 750 & 210 & 900 & 950 & 60 & 180 & 250 \\
\hline 192 & . & 65 & 360 & . & 80 & 190 & . & . & . \\
\hline
\end{tabular}


Table 12. Macoma balthica. Analysis of variance of effects of 8 zinc concentrations, 3 salinities and 3 temperatures on median survival times. DF: degrees of freedom; MS: mean sum of squares; $F$ : ratio of treatment mean square to error mean square

\begin{tabular}{|c|c|c|c|c|}
\hline Source of variation & DF & MS & $F$ & \\
\hline \multicolumn{5}{|l|}{ Temperature } \\
\hline$T$ & 1 & 51,750 & 62.1 & $\cdots$ \\
\hline $\mathrm{T}^{2}$ & 1 & 14,440 & 17.33 & $\cdots$ \\
\hline \multicolumn{5}{|l|}{ Concentration } \\
\hline $\mathrm{C}$ & 1 & 209,100 & 250.90 & $\cdots$ \\
\hline $\mathrm{C}^{2}$ & 1 & 25,720 & 30.86 & $\cdots$ \\
\hline \multicolumn{5}{|l|}{ Salinity } \\
\hline $\mathrm{S}$ & 1 & 109,500 & 131.39 & $\cdots$ \\
\hline $\mathrm{S}^{2}$ & 1 & 303 & 0.36 & NS \\
\hline \multicolumn{5}{|l|}{ Temperature $\times$ concentration } \\
\hline $\mathrm{TC}$ & 1 & 15,450 & 18.54 & $\cdots$ \\
\hline $\mathrm{T}^{2} \mathrm{C}$ & 1 & 98.84 & 0.12 & NS \\
\hline $\mathrm{TC}^{2}$ & 1 & 1,675 & 2.00 & NS \\
\hline $\mathrm{T}^{2} \mathrm{C}^{2}$ & 1 & 1,100 & 1.32 & NS \\
\hline \multicolumn{5}{|l|}{ Temperature $\times$ salinity } \\
\hline TS & 1 & 22,410 & 26.89 & $N \cdots$ \\
\hline $\mathrm{T}^{2} \mathrm{~S}$ & 1 & 731.0 & 0.88 & NS \\
\hline $\mathrm{TS}^{2}$ & 1 & 636.0 & 0.76 & NS \\
\hline$T^{2} S^{2}$ & 1 & 483.3 & 0.58 & NS \\
\hline \multicolumn{5}{|l|}{ Concentration $\times$ salinity } \\
\hline $\mathrm{CS}$ & 1 & 23,210 & 27.85 & $\cdots$ \\
\hline$C^{2} S$ & 1 & 5,552 & 6.66 & $\cdot$ \\
\hline $\mathrm{CS}^{2}$ & 1 & 1,520 & 1.82 & NS \\
\hline $\mathrm{C}^{2} \mathrm{~S}^{2}$ & 1 & 544.6 & 0.65 & NS \\
\hline Temperature $\times$ concentration $\times$ salinity (error) & 53 & 833.396 & & \\
\hline Total & 71 & & & \\
\hline
\end{tabular}

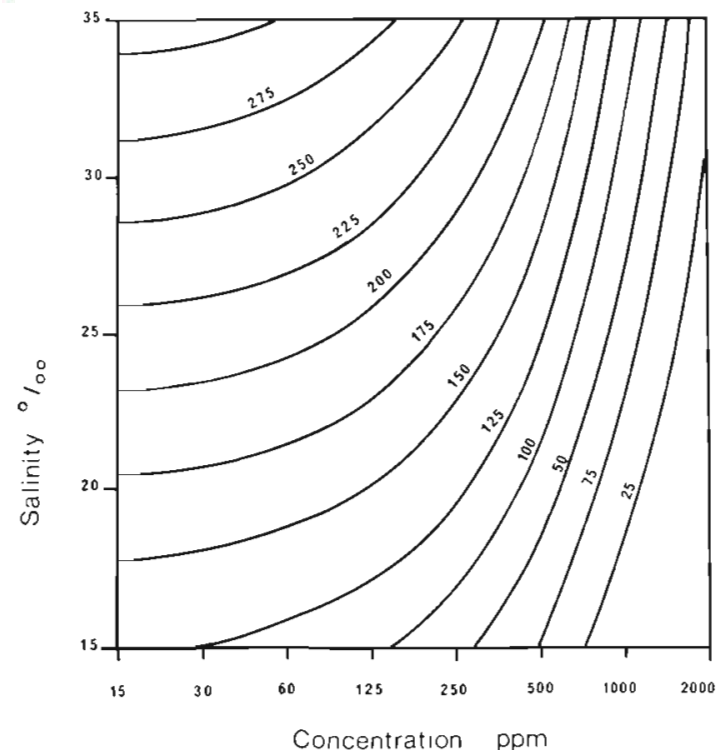

Fig. 11. Macoma balthica. Response surface showing combined effect of zinc concentration and salinity on median survival time, $\mathrm{LT}_{50}(\mathrm{~h})$, at $5^{\circ} \mathrm{C}$

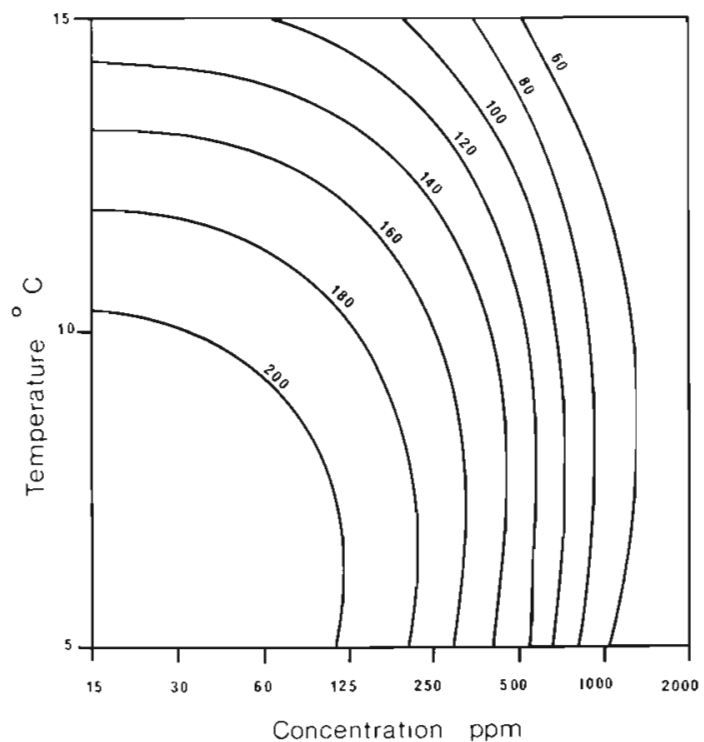

Fig. 12. Macoma balthica. Response surface showing combined effect of zinc concentration and temperature on median survival time, $\operatorname{LT}_{50}(\mathrm{~h})$, at $25 \%$ salinity 


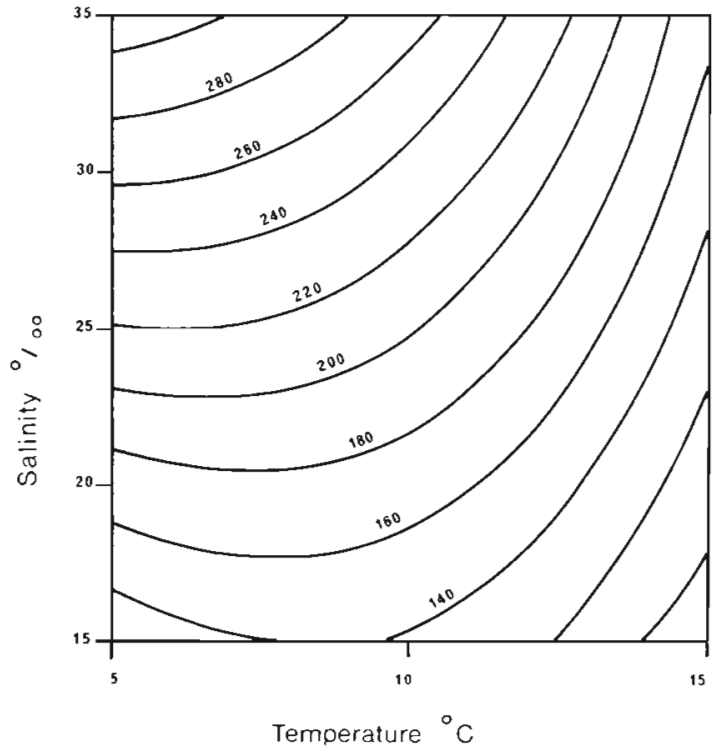

Fig. 13. Macoma balthica. Response surface showing combined effects of temperature and salinity on median survival time, $\mathrm{LT}_{50}(\mathrm{~h})$, at 15 ppm zinc concentration

factors for Mytilus edulis in a polluted estuary, found greater mortality at high temperature and high salinity than at low temperature and low salinity, whereas for $M$. balthica the greatest mortality occurred at high temperature and low salinity.

Phillips (1976) found no effects of either salinity or temperature on the net uptake of zinc by Mytilus edulis within the parameter limits tested (15 and $35 \%$;

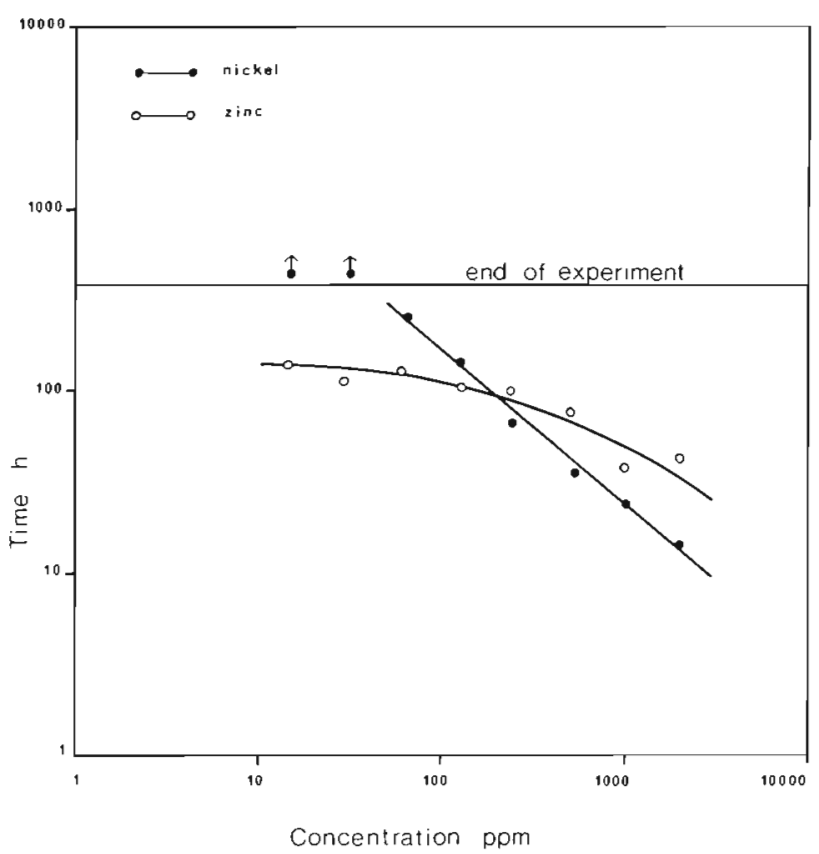

Fig. 14. Macoma balthica. Relation between exposure time and median lethal concentration of zinc and of nickel at $15^{\circ} \mathrm{C}$ and $25 \%$ salinity
10 and $18^{\circ} \mathrm{C}$ ). However subsequent experiments (Phillips 1977) suggested that the uptake of zinc from solution may be increased by the imposition of higher, stressful levels of salinity.

The $96 \mathrm{~h} \mathrm{LC}_{50} \mathrm{~s}$ for nickel for Corophium volutator which ranged from 5 to 54 ppm are also comparable with the value of $47 \mathrm{ppm} \mathrm{Ni}$ obtained by Eisler \& Hennekey (1977) for the hermit crab Pagurus longicarpus. Denton \& Burden-Jones (1982) reported $96 \mathrm{~h} \mathrm{LC}_{50} \mathrm{~s}$ for nickel from 2.8 to $21 \mathrm{ppm}$ for Penaeus merguiensis depending on the salinity-temperature combination. However $C$. volutator was most sensitive to nickel at combinations of low salinity and high temperature, whereas $P$. merguiensis exhibited maximum sensitivity under conditions of high salinity and high temperature.

The $96 \mathrm{~h} \mathrm{LC}_{50}$ values of zinc to Corophium volutator ranged from 1 to $16 \mathrm{ppm}$, low values occurring at low salinity and high temperature. These values are comparable with $96 \mathrm{~h} \mathrm{LC}_{50}$ values previously reported for marine and estuarine crustaceans which range from $0.29 \mathrm{ppm}$ Zn for Arctia tonsa (U.S. E.P.A. 1980) to $11.0 \mathrm{ppm} Z \mathrm{Zn}$ for Paragrapsus quadridentatus (Ahsanullah 1976).

The toxicity of zinc to Corophium volutator was decreased by increasing salinity and decreasing temperature; similar effects of temperature and salinity were shown by Jones (1975) on the toxicity of zinc to a variety of marine and estuarine isopods. Denton \& Burden-Jones (1982) also reported an increase in zinc toxicity to the juvenile banana prawn Penaeus merguiensis at higher temperatures, however in contrast to the present study, this was most noticeable at high rather than at low salinities.

As with previous studies of metal toxicity by the authors (Bryant et al. 1984), we conclude that dischargers of heavy metal to estuarine waters should consider carefully the effects of temperature and salinity on the toxicity of the effluents. In view of the variability of the response of the species of estuarine animals studied to different heavy metals, the effect of mixtures of metals should also be considered in future, as well as fluctuating conditions of temperature and salinity.

Acknowledgements. This study was supported financially by the WRc Environment, Stevenage and Medmenham. We thank especially G. Mance and R. Davies of WRc for advice and support. We further thank R. Lloyd for advice on the results, and $M$. Burnett for typing the manuscript.

\section{LITERATURE CITED}

Ahsanullah, M. (1976). Acute toxicity of cadmium and zinc to seven invertebrate species from Western Port, Victoria. Aust. J. mar. Freshwat. Res. 27: 187-96

Ahsanullah, M. (1982). Acute toxicity of chromium, mercury, 
molybdenum and nickel to the amphipod Allorchetes campressa. Aust. J. mar. Freshwat. Res. 33: 45-74

Anonymous (1980). SCA Biological Methods. Working Group 7.4. Acute toxicity tests in seawater. TTP31 (Revise IV). Standing Committee of Analysts, London

Babich, H., Stotsky, G. (1983). Temperature, pH, salinity, hardness and particulates mediate nickel toxicity to bacteria, an actinomycete and yeasts in lake simulated estuarine and sea waters. Aquat. Toxicol. 3: 195-208

Bryant, V., McLusky, D. S., Roddie, K., Newbery, D. M. (1984), Effect of temperature and salinity on the toxicity of chromium to three estuarine invertebrates (Corophium volutator, Macoma balthica, Nereis diversicolor). Mar. Ecol. Prog. Ser. 20: 137-149

Bryant, V., McLusky, D. S., Campbell, R., Newbery, D. M. (1985). Effect of temperature and salinity on the toxicity of arsenic to three estuarine invertebrates (Corophium volutator, Macoma balthica, Tubifex costatus). Mar. Ecol. Prog. Ser. 24: 129-137

Calabrese, A., Collier, R. S., Nelson, D. A., MacInnes, J. R. (1973). The toxicity of heavy metals to embryos of the american oyster Crassostrea virginica. Mar. Biol. 18: $162-166$

Calabrese, A., Nelson, D. A. (1974). Inhibition of embryonic development of the hard clam Mercenaria mercenaria, by heavy metals. Bull. environ. Contarn. Toxicol. 11: 92-97

Cotter, A. J. R., Phillips, D. J. H., Ahsanullah, M. (1982). The significance of temperature, salinity and zinc as lethal factors for the mussel Mytilus edulis in a polluted estuary. Mar. Biol. 68: 135-141

Davies, O. L. (1979). The design and analysis of industrial experiments. Longman, New York

Denton, G. W. R., Burdon-Jones, C. (1982). The influence of temperature and salinity upon the acute toxicity of heavy metals to the banana prawn (Penasus merguiensis de Man). Chemy Ecol. 1: 131-143

Eisler, R. (1977). Acute toxicities of selected heavy metals to the softshell clam Mya arenaria. Bull. envir Contam. Toxicol. 17: 137-145

Eisler, R., Hennekey, R. J. (1977). Acute toxicities of $\mathrm{Ca}^{2+}$, $\mathrm{Cr}^{6+}, \mathrm{Hg}^{2+}, \mathrm{Ni}^{2+}$ and $\mathrm{Zn}^{2+}$ to estuarine macrofauna. Arch. Envir. Contam. Toxical. 6: 315-323

Eldon, J., Pekkarinen, M., Kristoffersson, R. (1980). Effects of low concentrations of heavy metals on the bivalve Macoma balthica. Annls Zool. fenn. 17: 233-242
Franklin, A. L. (1980). Assessing the toxicity of industrial wastes, with particular reference to variations in sensitivity of test animals. MAFF Fish. Res. Techn. Rep. 61: 1-10

Fernandez, T. (1983). Some studies on the toxic effects of heavy metals to a polychaete, Hediste diversicolor (Müller) with particular reference to zinc. Ph. D. thesis, University of Hull

Jones, M. B. (1975). Synergistic effects of salinity, temperature and heavy metals on mortality and osmoregulation in marine and estuarine isopods (Crustacea). Mar. Biol. 30: $13-20$

Khayrallah, N., Jones, A. M. (1975). A survey of the benthos of the Tay estuary. Proc. R. Soc. Edinb. (B) 75: 113-135

Litchfield, J. T. Jr. (1949). A method for rapid graphic solution of time-percent curves. J. Pharmac. Exp. Ther. 97: 399-408

Lloyd, R. (1979). Toxicity tests with aquatic organisms. Lecture presented at the Sixth FAO/SIDA Workshop of Aquatic Pollution in relation to protection of living resources FAO, Rome, TF-RAD 112 (SWE) (Suppl. 1): 165-178

MacInnes, J. R., Calabrese, A. (1977). Responses of embryos of the american oyster, Crassostrea virginica to heavy metals at different temperatures. In: McLusky, D. S., Berry, A. J, (ed.) Physiology and behaviour of marine organisms. Proc. of the 12th Europ. Symp. on Mar. Biol., p. 195-202

McKenney, C. L., Neff, J. M. (1979). Individual effects and interactions of salinity, temperature, and zinc on larval development of the grass shrimp Paleomonetes pugio. I. Survival and developmental duration through metamorphosis. Mar. Biol. 52: 177-188

Phillips, D. J. H. (1976). The common mussel Mytilus edulis as an indicator of pollution by zinc, cadmium, lead and copper. I. Effects of environmental variable on uptake of metals. Mar. Biol. 38: 59-69

Phillips, D. J. H. (1977). Effects of salinity on the net uptake of zinc by the common mussel Mytilus edulis. Mar. Biol. 41: $79-88$

Portmann, J. E. (1968). Progress report on a programme of insecticide analysis and toxicity-testing in relation to the marine environment. Helgoländer wiss. Meeresunters. 17 : $247-256$

Schnute, J., McKinnell, S. (1984). A biologically meaningful approach to response surface analysis. Can. J. Fish. aquat. Sci. 41: 936-953

U.S. Environmental Protection Agency (1980). Ambient water quality criteria for zinc. Ref. No. EPA 440/5-80-07 